\title{
New pathological condition in cultured mulloway Argyrosomus japonicus: histopathological, ultrastructural and molecular studies
}

\author{
Dina Zilberg ${ }^{1}$, J. Brian Jones ${ }^{2}$, Mieke A. A. Burger ${ }^{2}$, Philip K. Nicholls $^{3}$, \\ Druime Nolan ${ }^{2}$, Melanie Crockford ${ }^{2}$, Fran Stephens ${ }^{2, *}$ \\ ${ }^{1}$ French Associates Institute for Agriculture and Biotechnology of Drylands, Blaustein Institutes for Desert Research, \\ Ben-Gurion University of the Negev, Midreshet Ben Gurion 84990, Israel \\ ${ }^{2}$ Fish Health Laboratory, Department of Fisheries, Government of, North Beach, Western Australia 6020, Australia \\ ${ }^{3}$ School of Veterinary and Biomedical Sciences, Murdoch University, Murdoch, Western Australia 6150, Australia
}

\begin{abstract}
Mulloway Argyrosomus japonicus is a native fish species in Western Australia, for which aquaculture production has recently been developed. A single cohort was stocked in a cage offshore at Geraldton, Western Australia, at a water depth of $6 \mathrm{~m}$. Fish appeared healthy before stocking. Routine histological analysis was carried out from 10 mo post stocking and until completion of harvest (about 2.5 yr post stocking). No gross pathology was evident. Microscopically, however, granulomatous lesions were present in the kidneys of almost $100 \%$ of the fish examined. Enclosed in the granuloma was an aggregate of organisms, 4.2 to $5.4 \mu \mathrm{m}$ in diameter. Kidney granulomas appeared as multi-focal aggregates. Granulomas at different stages of formation and finally fibrosing granulomas were observed. Granulomas also appeared infrequently in other organs: a few granulomas were found in the liver and spleen and a single granuloma in the heart of one fish. Transmission electron microscopy (TEM) revealed that the organism was composed of 2 cells, an outer cell enclosing an inner cell. The inner cell was surrounded by a double membrane and the outer cell by a single membrane. Cellular material, presumably of parasitic nature, surrounded the outer cell. The organism contained primitive mitochondria and abundant free ribosomes. Small subunit ribosomal DNA (SSU rDNA) sequence obtained by PCR revealed an $84 \%$ sequence identity with the myxosporean Latyspora scomberomori. Based on TEM and preliminary molecular results, we suggest that the organism is the extrasporogonic developmental stage of a myxozoan parasite, which failed to form spores in the mulloway host.
\end{abstract}

KEY WORDS: Granuloma $\cdot$ Parasite $\cdot$ Mulloway $\cdot$ Liver $\cdot$ Fish

\section{INTRODUCTION}

Mulloway Argyrosomus japonicus, order Perciformes, is an estuarine and coastal water fish distributed through the Indian and Western Pacific Oceans, occurring around Australia, Africa, India, Pakistan, China, Korea and Japan (Silberschneider \& Gray 2008). It provides important high value fisheries and is also a popular recreational angling fish. Research suggests that overfishing around southeastern Australia is leading to depletion of spawning stock (Silberschneider et al. 2009). Mulloway has been cultured for about $8 \mathrm{yr}$ at a few locations in Australia, including cage culture offshore in the Indian Ocean at Geraldton (Western Australia), and offshore and inshore in the Southern Ocean at Port Lincoln (South 
Australia). Mulloway has also been cultured in inland saline ponds in New South Wales. Western Australian production, thus far, has been limited to a single cohort of 50000 fish, investigated in the current study.

The main health problems described in mulloway include infection with ectoparasitic protozoans and monogenean trematodes that have been reported to cause mortalities in juvenile and adult mulloway (PIRSA 2001). The monogenean (Monopistocotylea, Capsalidae) Benedenia sciaenae was diagnosed in caged mulloway (Whittington 1996). Farmed mulloway from Port Lincoln had gills infested with Monogenea, Sciaenacotyle sciaenicola (Polyopisthocotylea) and Calceostoma glandulosum (Monopisthocotylea), and sea lice Caligus cf. elongatus (Copepoda: Caligidae) (Hayward et al. 2007).

In this case study of sea-caged mulloway in Western Australia, extensive kidney pathology was diagnosed. Based on a literature search, to our knowledge the condition has not been previously reported either in mulloway or other fish species. Although no evident adverse effect was noted, such as associated change in behavior, morbidity or mortality, estimated infection rate was close to $100 \%$. The aim of the present study was to characterize the pathology and describe the infecting organism.

\section{MATERIALS AND METHODS}

\section{Fish}

The fish studied were mulloway from a commercial aquaculture farm, Indian Ocean Fresh Australia, located at Geraldton, Western Australia $\left(28^{\circ} 45^{\prime} \mathrm{S}, 114^{\circ} 35^{\prime} \mathrm{E}\right)$. The fish were stocked in cages offshore in the Indian Ocean, at a water depth of about $6 \mathrm{~m}$. The farm was established in February 2008 with a single cohort of 50000 mulloway fingerlings obtained from the Challenger TAFE hatchery (Fremantle), that were stocked in a sea cage at the age of $50 \mathrm{~d}$. Health examination of 150 fingerlings was carried out before shipment to the sea cage. On arrival the fish were stocked into two $600 \mathrm{~m}^{2}$ D-nets within a single $60 \mathrm{~m}$ circumference circular cage. Post transport mortality of 924 out of 50000 fish was documented, but no parasite, bacterial infection or lesions were found in a sample of examined survivors. This was the only mulloway culture at Western Australia at the time and therefore all examinations were carried out on this stock.

\section{Fish sampling and histological analysis}

All health examinations were carried out in Perth at the Fish Health Laboratory, Department of Fisheries, Western Australia. From December 2008 to September 2010 (when the harvest was completed), 5 fish were sampled monthly for routine health check, i.e. a total of 105 fish. The fish were anaesthetized using AQUI-S. Organs were fixed in $10 \%$ neutral buffered formalin (NBF) and sent for histological processing and diagnosis at the Fish Health Laboratory. Organs sampled included liver, spleen, heart, gut, muscle, brain and kidney.

Samples were processed for histological analysis, embedded in paraffin blocks and sectioned at $5 \mu \mathrm{m}$. Sections were stained with haematoxylin and eosin (H\&E) using standard techniques. Additional stains applied included Giemsa, which is used to stain protozoa and produces a pronounced staining of microsporidian polar capsule, as well as Grocott, a silver stain, and Periodic Acid Schiff (PAS), which both stain carbohydrates and are used to demonstrate fungal organisms. Positive controls were used to validate the stains as per the laboratory's ISO 17205 accreditation. Slides were examined under a light microscope (Olympus BX51) and documented with an attached camera (Olympus DP70).

\section{Transmission electron microscopy (TEM)}

Kidneys were dissected from deeply anaesthetized fish, immediately trimmed to a size of $1 \mathrm{~mm}$ or less and fixed in $2.5 \%$ cold gluteraldehyde in $0.1 \mathrm{M}$ cacodylate buffer ( $\mathrm{pH}$ 7.4). Samples were post fixed in $1 \%$ osmium tetroxide, embedded in Epon, sectioned and stained with uranyl acetate lead citrate and examined with a Philips CM10 Transmission Electron Microscope.

\section{DNA analysis}

Samples included for DNA analysis are listed in Table 1. DNA was extracted from frozen kidney tissue and flesh samples using DNAzol (Invitrogen) solution as described in Crockford et al. (2005). DNA was extracted from paraffin blocks using QuickExtract FFPE DNA Extraction Kit (Epicentre Biotechnologies) as per the manufacturer's specifications. Granulomas from infected kidneys were also cut by laser micro-dissection on a Leica LMD 6500 microscope and DNA was successfully extracted from this 
Table 1. Samples used to identify the kidney pathogen in mulloway and results for each sample using the nested PCR for Myxosporea as described in Fiala (2006). Samples are listed as case numbers from frozen kidney, paraffin embedded tissues (FFPE), laser microdissected tissues (LMD) and flesh preserved in $100 \%$ ethanol. The primary PCR, using primers ERIB1 and ERIB10, amplifies any universal eukaryote ( 1400 bp expected size) and the nested PCR, using primers myxospec $\mathrm{F}$ and myxospec $\mathrm{R}$, targets specific Myxosporea (900 bp expected size). Amplicons that showed a product of $900 \mathrm{bp}$ following nested PCR were

\begin{tabular}{|lcc|}
\hline Sample description & Primary PCR & Nested PCR \\
\hline FH09-128 frozen kidney 2 & + /- & - \\
FH09-128 frozen kidney 3 & + & - \\
FH09-128 frozen kidney 4 & + & + \\
FH09-128 frozen kidney 5 & + & + \\
FH09-128 FFPE tissues 2 & - & - \\
FH09-128 FFPE tissues 3 & - & - \\
FH09-128 LMD 1 & - & - \\
FH09-128 LMD 2 & - & + \\
FH09-128 LMD 3 & - & - \\
FH10-101 frozen kidney 2 & - & + \\
FH10-101 frozen kidney 3 & + & - \\
FH10-101 frozen kidney 4 & + - & - \\
FH10-101 frozen kidney 5 & - & - \\
FH10-101 K frozen kidney 2 & + & - \\
FH10-101 K frozen kidney 3 & - & + \\
FH10-101 K frozen kidney 4 & +++ & + \\
FH10-101 K frozen kidney 5 & + & + \\
FH12-12 Flesh 4 & + & \\
FH12-12 Flesh 5 & + & \\
FH12-12 Flesh 6 & &
\end{tabular}
sequenced and matched best with Latyspora scomberomori

positive control. The positive control used for the myxosporean and universal eukaryote PCR tests was an uncharacterized muscledwelling Unicapsula sp. (Myxosporea: Multivalvulida) ex Seriola lalandi; Unicapsula sp. spore DNA was extracted by tissue preparation and DNA extraction from frozen fish tissue as per Burger \& Adlard (2010). The identity of the myxosporean as coming from the genus Unicapsula was confirmed by visualization of spores using light microscopy and sequencing of the SSU as per Burger \& Adlard (2010). NCBI BLAST results showed $97 \%$ sequence identity to Unicapsula sp. 18S SSU ribosomal RNA, partial sequence (Genbank accession number AY302725).

PCR products of the expected size were extracted using a freeze-squeeze method as described in Crockford et al. (2005). Purified PCR products were sent to the Australia Genome Research Facility (Perth) for sequencing using their standard protocol.

The resulting consensus sequence was aligned with a selected group of other myxozoan SSU sequences from the marine urinary clade and representative of species from each of the other clades, selecting particularly species that infect the kidney (from Bar-

tissue using the QIAamp DNA FFPE Tissue Kit (QIAGEN). PCR tests were carried out using generic primers on the DNA for various groups of organisms that the parasite was suspected to belong to, including Fungi, Myxozoa, and Protozoa. The primers are shown in Table 2.

Testing also included a nested PCR. A primary PCR was set up to amplify the Small subunit ribosomal DNA (SSU rDNA) gene using universal eukaryotic primers ERIB1 and ERIB10 (Barta et al. 1997); $1 \mu \mathrm{l}$ of product from the first round PCR was used as template for the nested PCR using myxosporean specific SSU rDNA primers MyxospecF and MyxospecR (Fiala 2006). PCR reactions were made up with $\sim 300 \mathrm{ng}$ of DNA template, $12.5 \mu \mathrm{l}$ of $2 \mathrm{X}$ BioMix $^{\mathrm{TM}}$ Red (Bioline), and $1 \mu \mathrm{l}$ of $10 \mu \mathrm{M}$ primer made up to $25 \mu \mathrm{l}$ reactions. Cycling of PCR reactions was carried out in a cp2-01 thermocycler (Corbett Research) as per conditions shown in Table 2. All PCR products were analyzed by $1.5 \%$ agarose gel electrophoresis and visualized by UV transillumination for a band of the estimated size.

For the fungal and lower eukaryote PCR tests Saccharomyces cerevisiae (bakers yeast) was used as a tošová et al. 2011), plus Kudoa neurophila ex Seriola lalandi (collected from a similar geographic locality to the mulloway parasite). Alignment was carried out using ClustalW within Geneious Pro ${ }^{\mathrm{TM}}$ (Drummond et al. 2011) with gap open cost 10 and gap extend cost 2 . A distance neighbor-joining tree with bootstrap supports based on 1000 replicates and pairwise distance matrix was generated (also in Geneious Pro ${ }^{\mathrm{TM}}$ ) from a trimmed alignment (to the full length of the mulloway parasite sequence) to demonstrate the basic relationship of this organism with other myxozoans using the Geneious tree builder with genetic distance model Tamura-Nei. The malacosporean Boddenbrockia plumatellae (Genbank accession number FJ981824) was used as an outgroup.

\section{RESULTS}

A total of 105 fish were histologically examined from December 2008 to September 2010 (5 fish mo ${ }^{-1}$ ). Other infections that were diagnosed in these seacaged fish included: systemic bacterial infections by Vibrio harveyi and Photobacterium damselae; 


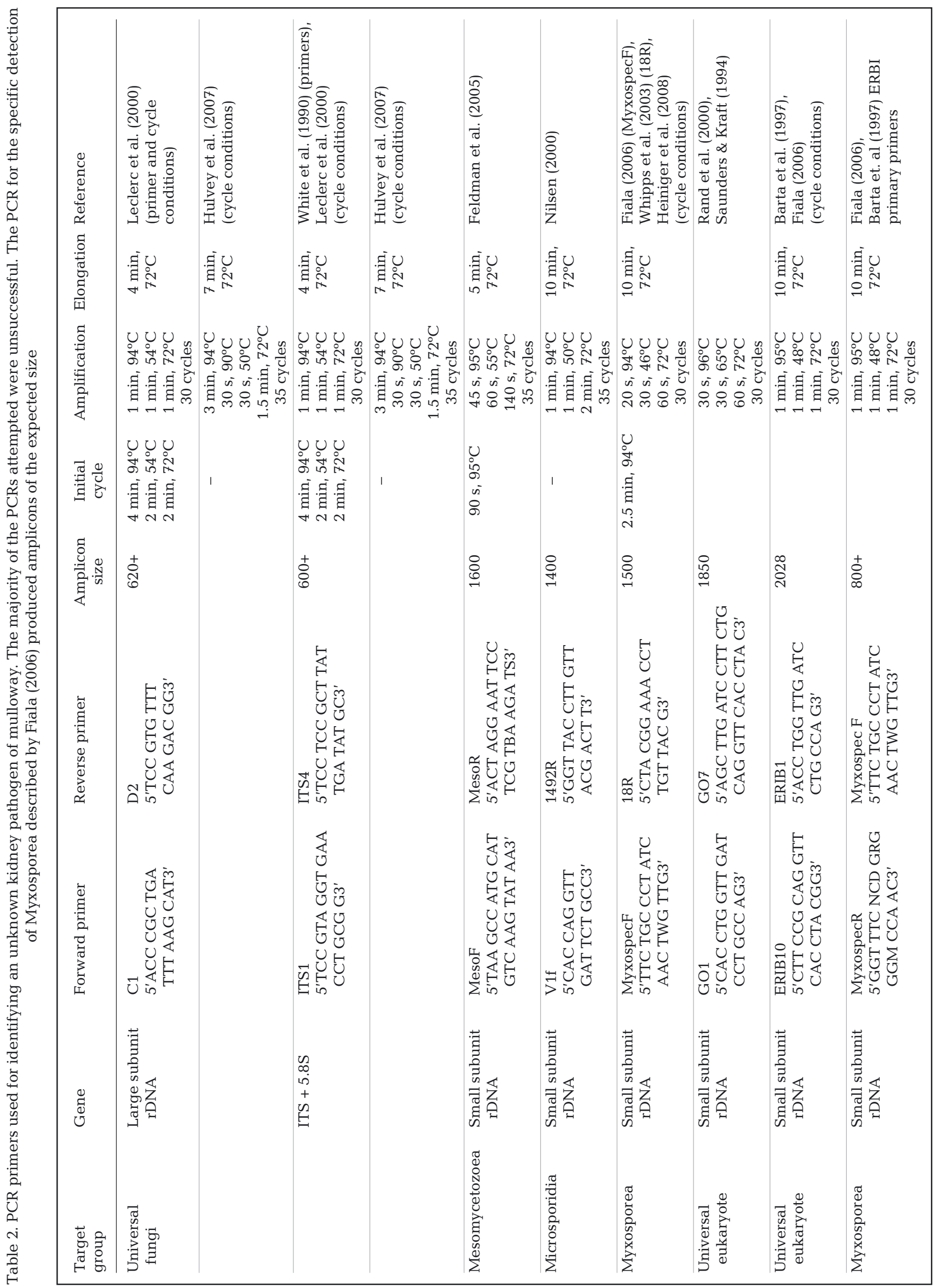


parasitic infections by monogenean parasites, most commonly gill flukes, including a blood-feeding polyopisthocotylean morphologically similar to $S C i-$ aenacotyle sciaenicola; a monopisthocotylean resembling Calceostoma glandulosom; and the capsalid skin fluke Benedinia scianiae (monopisthocotylean). The latter was the most significant in terms of morbidity and mortality.

\section{Histopathology}

Macroscopically, no lesions were evident and all internal organs appeared normal. Histological analysis of fixed tissues revealed granulomatous lesions, mainly in the kidney, where they were present in all the examined fish. Focal aggregates as well as focal single granulomas were seen in the kidney. Granulomas were typically characterized by a thick wall composed mainly of layered macrophages/epithelioid cells and an outer layer of fibroblasts with little or no fibrous material (Fig. 1). Inside the granuloma was an aggregate of round shaped organisms with a diameter of 4.2 to $5.4 \mu \mathrm{m}$ (average $4.7 \mu \mathrm{m}, \mathrm{n}=25$ ). Granulomas appeared individually or in clusters (Fig. 1).

Occasionally an aggregate of organisms surrounded by macrophages but no well-developed granuloma could be seen (Fig. 2). These were few compared to the granuloma-surrounded aggregates and were presumed to be a developing granuloma following a recent invasion of the organism. The few granulomas found in the spleen were thin-walled and surrounded by melanomacrophages (Fig. 3).

The organism was characterized by a central round light basophilic circle with darker basophilic staining at the periphery, with an average diameter of $2.33 \mu \mathrm{m}(\mathrm{n}=25)$, which was assumed to be the nucleus with marginated chromatin. This organelle was surrounded by an eosinophilic, slightly foamy cytoplasm. An elliptical basophilic organelle was present at the edge of the cytoplasm, adjacent to the cell membrane (Fig. 1); this was later revealed to be the nucleus of the outer cell, as observed under TEM (see Fig. 11b). In aggregates that were not surrounded by a fully developed granuloma, the organism appeared less circular and the cytoplasm appeared more foamy (Fig. 2).

Granulomas were mainly present in the kidney, but sporadic granulomas (1 to 2 per section) were identified in the liver and spleen of about $50 \%$ of the fish. In the liver, granulomas were usually, but not always, associated with the hepatopancreas and blood vessels (Fig. 4). In one case, an aggregate of the organism surrounded by macrophages was lodged on or adjacent to and distorting a hepatic blood vessel wall (Fig. 5). It is possible that the organism had entered the circulation and attached itself to the wall of the hepatic blood vessel on its way to invade the liver (Fig. 5). In the spleen, most of the granulomas were thin walled and surrounded by macrophages containing brownish pigment (Fig. 3). In one fish a single granuloma was found in the heart (Fig. 6). Fibrosing granulomas contained eosinophilic stained amorphous material and a thickened cellular capsule where the parasite appeared to have been destroyed (Figs. 4 \& 7).

Throughout the sampling period, both fibrosing granulomas (with no live organism) and what appeared to be new granulomas were evident and infection was heavy throughout the study.

In an attempt to identify the nature of the organism several histological stains were applied. The parasite did not have the pronounced staining with Giemsa that is characteristic of polar capsules within myxozoan spores (Fig. 8). It was strongly argyrophilic, as it stained with Grocott (Fig. 9) and with PAS (not shown), both of which positively stain fungus.

\section{TEM}

TEM revealed that the organism enclosed in the granuloma was composed of 2 cells, i.e. a peripheral cell (average size $4.9 \times 6.4 \mu \mathrm{m}, \mathrm{n}=5$ ) surrounding a central cell (Figs. $10 \& 11$ ). Each cell contained a nucleus (average size $1.9 \mu \mathrm{m}, \mathrm{n}=8$ ). The outer cell appeared to be surrounded by more cellular material. The nucleus of the central cell was centrally located (Fig. 10) and that of the peripheral cell was often flattened against the outer cell membrane (Fig. 11c). The central cell appeared to be surrounded by a double cell membrane whereas the membrane of the outer cell was single layered (Fig. 11).The organism contained a primitive mitochondria and abundant free ribosomes (Fig. 11). Epithelioid cells surrounded organism aggregates and cellular material of unidentified nature. Tight junctions were evident between the epithelioid cells. There were no evident host cells within the granuloma.

\section{DNA analysis}

All PCR methods attempted are shown in Table 2. PCR analysis using primers for Mesomycetozoea and Microsporidia produced no product. However, some 

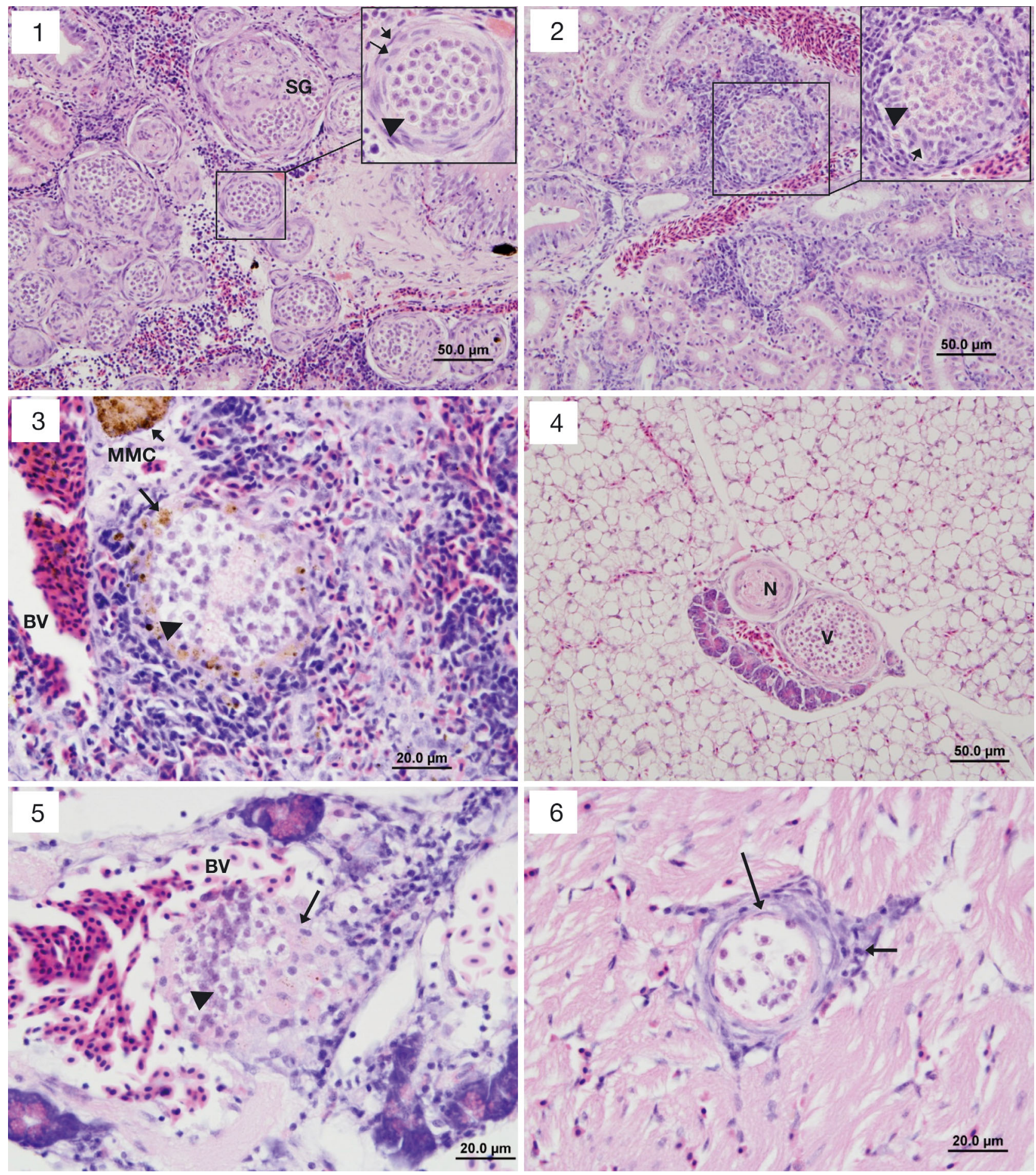

Figs. 1 to 6. Argyrosomus japonicus. Granulomas in the kidney and other organs of mulloway. Fig. 1. Granulomas in the kidney containing the infecting organism (arrowhead), enclosed by layers of epithelioid cells (long arrow) and a second layer of fibroblasts (short arrow). SG: split granuloma. Fig. 2. Aggregate of the infecting organism (arrowhead) in the kidney (presumably a newly developing granuloma), surrounded by haematopoietic tissue and/or mononuclear inflammatory cells and few macrophages/epithelioid cells (arrow). Parasite cells at the center of the granuloma display foamy eosinophilic cytoplasm. Fig. 3. Granuloma in the spleen, enclosing the infecting organisms (arrowhead) surrounded by a thin layer of macrophages containing brown pigment (arrows). BV: blood vessel; MMC: melanomacrophage center. Fig. 4. Hepatic granulomas, containing viable infecting organism $(\mathrm{V})$ and a parasite-free granuloma with a necrotic core $(\mathrm{N})$ in the hepatopancreas. H\&E staining. Fig. 5. Aggregate of the infecting organism (arrowhead) surrounded by macrophages (arrow), located in or adjacent to a hepatic blood vessel (BV). Fig. 6. Granuloma in the heart containing the infectious organism surrounded by fibroblasts (long arrow) and inflammatory cells (short arrow) 

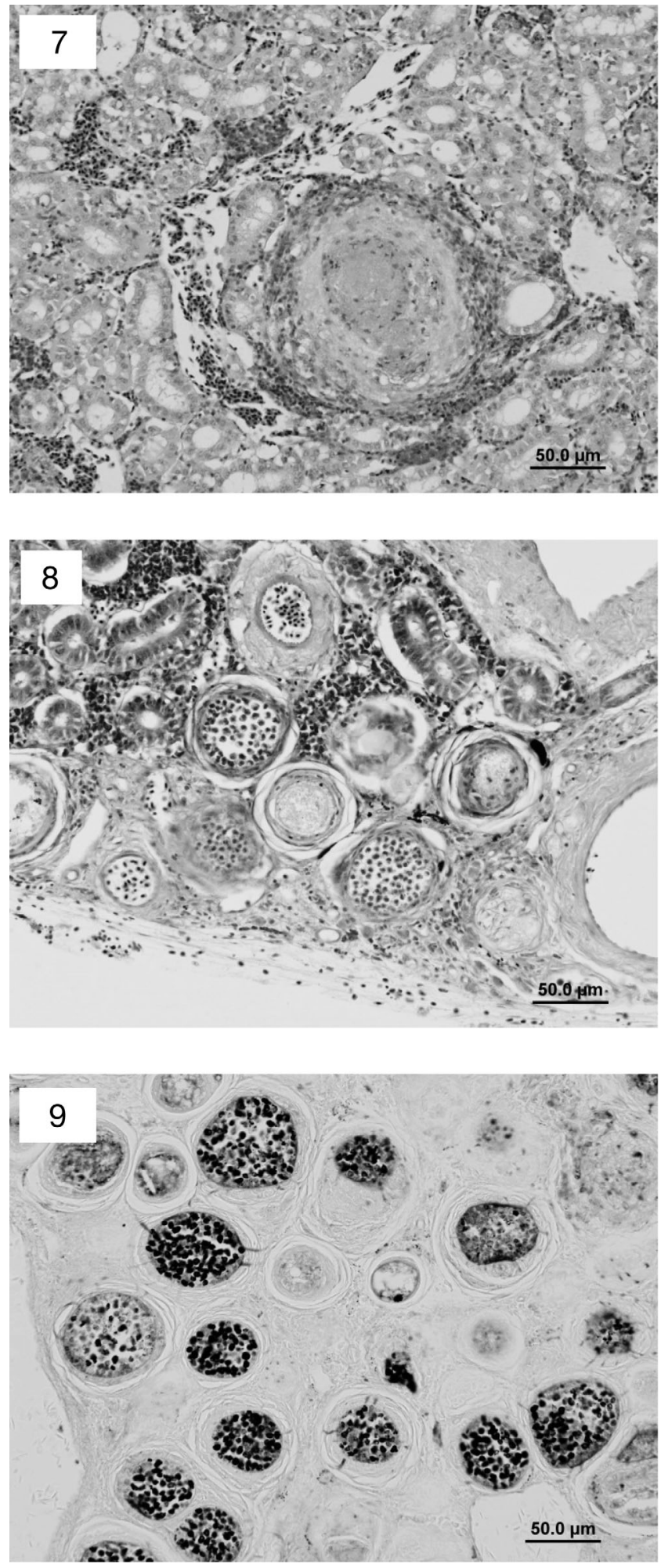

Figs. 7 to 9. Argyrosomus japonicus. Fig. 7. Fibrosing granuloma in the kidney. Organisms were unidentifiable in the core. Fig. 8. Kidney granulomas stained with Giemsa. Fig. 9. Silver staining (Grocott), showing intense staining of the infecting organism in kidney granulomas
DNA amplification was achieved using the DNAzol extracted samples with primer combinations C1 and D2 for the large subunit rDNA (Leclerc et al. 2000) and ITS1 and ITS4 for the internal transcriber gene region (White et al. 1990), under cycling conditions as per Hulvey et al. (2007). None of the 4 forward and 4 reverse ITS samples sequenced well. Of the 12 large subunit sequencing reactions carried out $(6$ each with primers C1 and D2), one C1 sequence produced a quality sequence for $400 \mathrm{bp}$ of the $721 \mathrm{bp}$ fragment. Because only one forward primer was successful in amplifying any useful DNA and the sequence produced was sub-optimal, a consensus sequence could not be obtained. The TEM suggested that the organism was a myxosporidian, so this sequence was aligned with known myxosporean sequences from Freeman et al. (2008). The partial sequence obtained had $85 \%$ sequence identity to Kudoa ovivora 28S large subunit ribosomal RNA gene, partial sequence (GenBank accession number AY302731.1) using NCBI BLAST. Therefore further PCR tests using more myxosporean specific primers were carried out as follows.

The template from a primary reaction using ERIB1and ERIB10 primers for SSU rDNA (Table 2) was used in a nested reaction with MyxopsecF and MyxospecR primers, with a target PCR product of approximately $900 \mathrm{bp}$ (Table 2, Fig. 12). Out of 20 samples tested, 8 positive products (including one from a Laser microdissected granuloma) were obtained with the nested PCR. The bands obtained from 4 positive samples are presented in Fig. 12.

This product was sequenced and submitted to GenBank (accession number JQ868766). Using NCBI BLAST, the consensus sequence revealed $84 \%$ sequence identity with Latyspora scomberomori 18S SSU rDNA gene (GenBank accession number HM230826) with $100 \%$ coverage of the 863 nucleotide query.

The trimmed alignment generated with other myxozoan SSU sequences consisted of 1106 characters which spanned the entire mulloway parasite sequence. The overall distance relationships can be seen in the neighbor-joining tree in Fig. 13. The percentage similarities between the sequences included in the analysis are shown in Table S1 in the supplement at www.int-res.com/articles/suppl/d100p219_ supp.pdf. The mulloway parasite sequence shows most similarity to Latyspora scomberomori (Bartošová et al. 2011) from the family Sinuolineidae, but at a low level (81.9\% identity from the alignment), and secondly to Zchokkella lophii (Freeman et al. 2008) from the family Myxidiidae (74.7\% identity). 


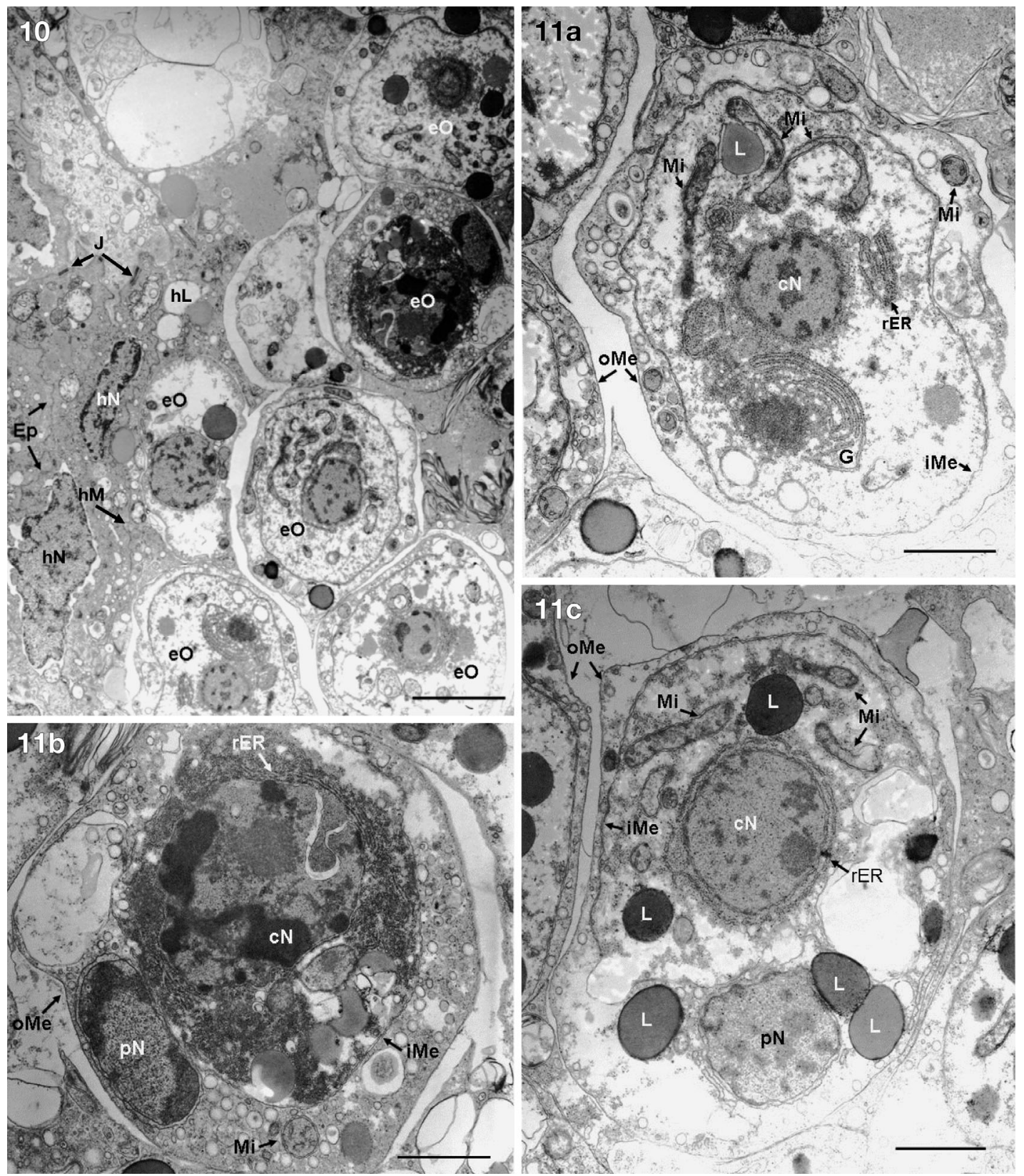

Figs. 10 \& 11. Argyrosomus japonicus. TEM images of a granuloma. Fig. 10. Edge of a granuloma showing host epithelioid cells $(\mathrm{Ep})$ and 6 of the encysted organisms $(\mathrm{eO})$. Scale bar $=11.26 \mu \mathrm{m}$. Fig. 11a-c. Encysted organisms within a granuloma. Scale bars $=2.56 \mu \mathrm{m}$. rER: rough endoplasmic reticulum; G: Golgi; J: host cell junctions; L: lysosome; hL: hosl lipid vacuole; hM: host cell membrane; iMe: inner cell membrane; oMe: outer organism's membrane; Mi: mitochondria; cN: central nucleus; hN: host nucleus; pN: peripheral nucleus

\section{DISCUSSION}

The reported study suggests that the lesions identified mainly in the kidney but also in other organs are granulomatous in nature and the cells present in these granulomas are of parasitic origin. This parasite appears to be the causative agent of the described pathology.
The parasites stained positive with Grocott staining (a silver stain) and PAS. In the Grocott stain, chromic acid oxidation forms aldehydes from polysaccharide components, for example in the fungal cell wall, which are subsequently demonstrated by reduction of an alkaline hexamine-silver complex that precipitates and blackens the tissue. Thus, the positive staining suggests the presence of polysaccharide. 


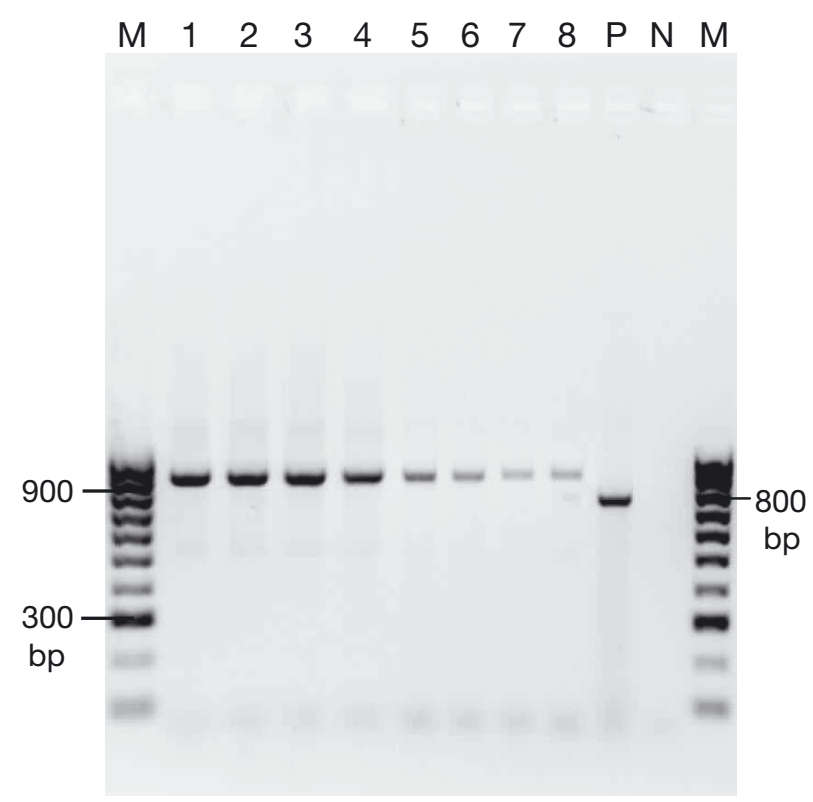

Fig. 12. PCR products amplified by nested PCR using primers MyxospecF and MyxospecR (Fiala 2006). M: 100 bp DNA ladder marker; Lanes 1 to 8: PCR products in duplicate from DNA extractions FH09-128 \#4 (Lanes 1+2), FH09-128 \#5 (Lanes 3+4), FH09-128 LMD Cs (Lanes 5+6), and FH10101 \# 3 (Lanes 7+8); N: no template control (negative control); P: positive control (undescribed muscle-dwelling microsporidian, Unicapsula sp. ex Seriola lalandi)
According to the TEM analysis, the organism does not have the cell wall characteristic of fungi. However, some myxosporidians do stain with silver stains (Wolf \& Markiw 1979)

Fish initially stocked from the hatchery appeared healthy with no evident pathology (by histology). Granulomas were present when routine histological assessment began, 10 mo post stocking. Possibly the fish encountered the pathogen shortly after arrival to the culture site, and within 10 mo the infection was well established. Granulomas appeared as individual or split. The latter could have been formed by macrophages infiltrating between the enclosed organisms or on exit of the organism and the formation of coalescing granulomas.

TEM analysis revealed that the organism was multicellular. The innermost cell was surrounded by a double membrane and enclosed within the cytoplasm of a larger cell (enclosing cell). Enclosing cells appeared to be surrounded by cytoplasm of a third larger cell (Fig. 10). Assuming that the third outer cell is parasitic in nature, this can be interpreted as being a primary cell that contains a large number of secondary cells, most of which enclose a tertiary cell, thus presenting a polysporic pseudoplasmodia (Lom \& Dykova 1992). Alternatively the parasite may be in

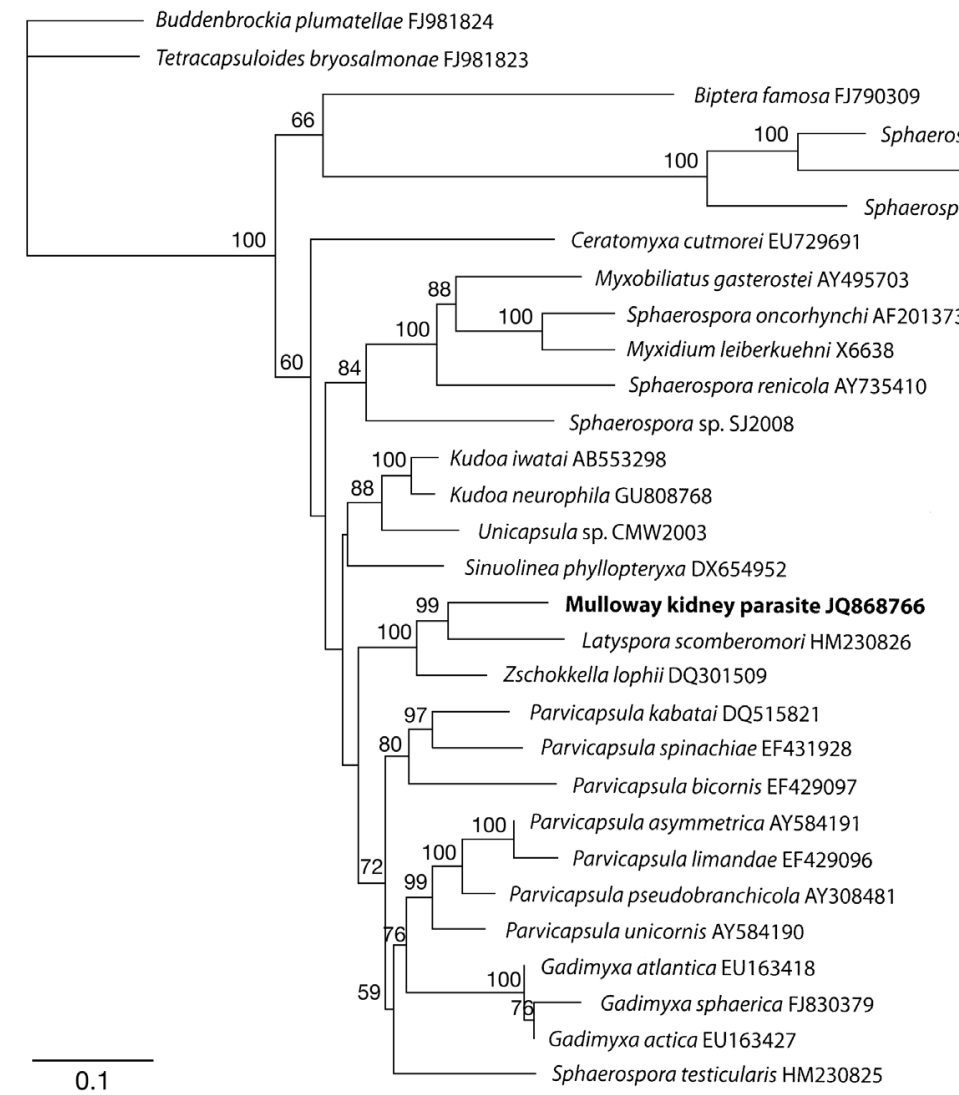

Fig. 13. Neighbor-joining distance tree of partial small subunit rDNA including the novel mulloway kidney parasite with other myxozoan organisms from an alignment of 1106 characters. Bootstrap values based on 1000 replicates 
the form of pseudoplasmodia aggregates (large number of primary cells containing a single secondary cell each). Myxosporean cells contain most of the cytoplasmic organelles, constituents and reserve materials (fat, glycogen) of an animal cell (Lom \& Dykova 1992). The abundant free ribosomes observed in the mulloway parasite are characteristic of myxozoans, especially in extrasporogonic stages (Lom \& Dykova 1992).

Myxosporeans are known to have a proliferative stage in their life cycle (Lom \& Dykova 1992). This stage is localized in sites or organs different from the sporogonic phase. At this stage, development starts with growth and nuclear division, producing an inner secondary cell within the primary cell, within a tightly fitting membrane bound vacuole, a significant characteristic in myxosporeans (Lom 1987, Lom \& Dykova 1992). A primary cell containing a secondary cell was demonstrated for Myxidium lieberkuhni (see Lom 1987). Primary cells of an unknown myxosporidian infecting coho salmon Onchorhynchus kisutch kidneys, CKX, contained one to several secondary cells (Jones et al. 2004). CKX is different from the described infection as it occurs intracellularly and primary cells contain one or more secondary cells, as opposed to a single secondary cell in the mulloway parasite. Sphaerospora renicola, a myxozoan parasite infecting carp Cyprinus carpio, has extrasporogonic development occurring in the bloodstream where a primary cell containing a single secondary cell is formed, growing into 8 secondary cells, each containing a tertiary cell (Lom \& Dykova 1992). The primary cells then fall apart and the released secondary cells restart the cycle either in the bloodstream, the swim bladder (where inflammatory response is associated) or reach the kidney to initiate sporogonic development (Lom \& Dykova 1992). Such extrasporogonic proliferation may have occurred in the mulloway, producing the extensive infection described. A similar form of extrasporogonic proliferation and formation of a monosporic plasmodia was reported for Tetracapsuloides bryosalmonae, a malacosporean species (a different myxozoan class to the Myxosporea) identified as the causative agent of proliferative kidney disease (Feist \& Longshaw 2006).

Lack of mature spores made the classification of the mulloway parasite much more complicated, as characteristic histological stains for myxozoans failed to demonstrate the nature of this organism. Similarly, the extrasporogonic stages of Tetracapsuloides bryosalmonae do not stain positively with Giemsa (Ferguson 2006). Infection with $T$. bryosalmonae results in a host response characterized by granuloma formation in the kidney, similar to the pathology observed in the mulloway. However, significant tissue damage is associated with $T$. bryosalmonae infection in salmonid hosts (Feist \& Longshaw 2006). In contrast, the granulomatous response in mulloway was of a chronic nature, with no obvious implication on fish health. T. bryosalmonae infection in Arctic char results in a large number of spores without an extensive host reaction (Feist \& Longshaw 2006), suggesting host specificity for $T$. bryosalmonae with Arctic char.

From the many primer sets used in this study (Table 2) only the nested PCR using template from the universal eukaryotic primers ERIB1 and ERIB10 and then the myxosporean specific MyxospecF/ MyxospecR PCR primer combination (Fiala 2006) proved able to amplify an appropriately sized SSU rDNA fragment from the mulloway kidney. The fragment had an $81.9 \%$ pairwise identity based on neighbor-joining analysis with the myosporean Latyspora scomberomori (family Sinuolineidae); this species also infects kidney tissue of fish (Scomberomorus guttatus) but as mature spores in the kidney tubules (Bartošová et al. 2011). Without mature spores, it is still difficult to assign the mulloway parasite even to family level using the DNA data. For example, the family Sinuolineidae is not monophyletic and there is as low as $48 \%$ sequence identity between 2 species from this family, Biptera formosa (FJ790309) and Latyspora scomberomori (HM230826), over this region of the SSU (see Fig. 13). Perhaps the association between these 2 sequences is derived more from their tissue tropism, which is known to be a considerable correlating factor in sequence similarities in the Myxosporea (Burger et al. 2007). Overall, this DNA sequence similarity, together with the TEM evidence, indicates that that the mulloway parasite is a novel myxosporean.

The importance of myxosporean parasite infections in cultured fish is increasing (Bartošová et. al 2011). Diagnosis of pathogens is not always straightforward. There have been other reported pathogenassociated pathological conditions in fish which were not identified, or that were only fully or partially identification after a considerable time. For example the X-cell parasite, originally described in 1969 (Brooks et al. 1969), was only years later identified as a protozoan, related to Haplosporidia, using molecular techniques (Miwa et al. 2004). A parasitic amoeba-like organism was described in granulomatous lesions of goldfish, the taxonomy of which is yet to be finalized (Dykova et al. 1996). Recently Con- 
stenla \& Padrós (2010) have reported a new pathological condition in sole Solea senegalensis, associated with a unicellular parasite of unknown nature.

Infection occurred within the sea cage, since no infection was apparent in fish prior to them being stocked in the sea cage. From our observation the host response appeared to eventually destroy the enclosed organism and there was no evidence of progression to spore formation in the mulloway.

Further research is needed to determine the route of transmission of this parasite, including identification of potential alternate hosts (presumably an annelid worm or a bryozoan, if this is indeed a myxozoan parasite) at the culture site and transmission experiments to determine whether the life cycle can be completed in the mulloway.

Acknowledgements. We thank E. Starling, owner of Indian Ocean Fresh Australia fish farm for her cooperation throughout the project and for routinely providing samples for our investigation. We thank K. Eliott, from the Department of Agriculture and Food, Western Australia, for his expertise and help with the electron microscope processing and analyses. M. Snow made valuable comments on the manuscript and helped with the sequence alignments. We thank G. Partridge from Challenger TAFE (Fremantle) for his input in background information on the mulloway cohort stocked in IOFA.

\section{LITERATURE CITED}

Barta JR, Martin DS, Liberator PA, Dashkevicz M and others (1997) Phylogenetic relationships among eight Eimeria species infecting domestic fowl inferred using complete small subunit ribosomal DNA sequences. J Parasitol 83: 262-271

Bartošová P, Freeman MA, Yokoyama H, Caffara M, Fiala I (2011) Phylogenetic position of Sphaerospora testicularis and Latyspora scomberomori n. gen. n. sp. (Myxozoa) within the marine urinary clade. Parasitology 138: 381-393

> Brooks RE, McArn GE, Wellings SR (1969) Ultrastructural observations on an unidentified cell type found in epidermal tumors of flounders. J Natl Cancer Inst 43:97-109

> Burger MAA, Adlard RD (2010) Four new species of Kudoa Meglitsch, 1947 (Myxosporea: Multivalvulida) from Australia with recommendations for species descriptions in the Kudoidae. Parasitology 137:793-814

> Burger MAA, Cribb TH, Adlard RD (2007) Patterns of relatedness in the Kudoidae with descriptions of Kudoa chaetodoni n. sp. and K. lethrini n. sp. (Myxosporea: Multivalvulida). Parasitology 134:669-681

Constenla M, Padrós F (2010) Histopathological and ultrastructural studies on a novel pathological condition in Solea senegalensis. Dis Aquat Org 90:191-196

Crockford M, Jones JB, Crane MSJ, Wilcox GE (2005) Molecular detection of a virus, Pilchard herpesvirus, associatedwith epizootics in Australasian pilchards Sardinops sagax neopilchardus. Dis Aquat Org 68:1-5
Drummond AJ, Ashton B, Buxton S, Cheung M and others (2011) Geneious v5.4. www.geneious.com/

Dykova I, Lom J, Machackova B, Sawyer TK (1996) Amoebic infection in goldfishes and granulomatous lesions. Folia Parasitol 43:81-90

Feist SW, Longshaw M (2006) Phylum Myxozoa. In: Woo PTK (ed) Fish diseases and disorders, 2nd edn. CABI, Wallingford, p 230-296

Feldman SH, Wimsat JH, Green DE (2005) Phylogenetic classification of the frog pathogen Amphibiothecum (Dermosporidium) penneri based on the small ribosomal subunit sequencing. J Wildl Dis 41:701-706

Ferguson HW (2006) Systemic pathology of fish: a text and atlas of normal tissues in teleosts and their responses in disease, 2nd edn. Scotian Press, London

Fiala I (2006) The phylogeny of Myxosporea (Myxozoa) based on small subunit ribosomal RNA gene analysis. Int J Parasitol 36:1521-1534

Freeman MA, Yokoyama H, Ogawa K (2008) Description and phylogeny of Ceratomyxa anko sp. n. and Zschokkella lophii sp. n. from the Japanese anglerfish, Lophius litulon (Jordan). J Fish Dis 31:921-930

> Hayward CJ, Bott NJ, Itoh N, Iwashita M, Okihiro M, Nowak BF (2007) Three species of parasites emerging on the gills of mulloway, Argyrosomus japonicus (Temminck and Schlegel, 1843), cultured in Australia. Aquaculture 265:27-40

> Heiniger H, Gunter NL, Adlard RD (2008) Relationships between four novel ceratomyxid parasites from the gallbladders of labrid fishes from Heron Island, Queensland, Australia. Parasitol Int 57:158-165

Hulvey JP, Padgett DE, Bailey JC (2007) Species boundaries within Saprolegnia (Saprolegniales, Oomycota) based on morphological and DNA sequence data. Mycologia 99: 421-429

> Jones S, Prosperi-Porta G, Dawe S, Blackbourn J, Taylor K, Lowe G, Osborn A (2004) Proliferative renal myxosporidiosis in spawning coho salmon (Oncorhynchus kisutch) in British Columbia and Washington. Folia Parasitol 51:221-227

> Leclerc MC, Guillot J, Deville M (2000) Taxonomic and phylogenetic analysis of Saprolegniaceae (Oomycetes) inferred from LSU rDNA and ITS sequence comparisons. Antonie Van Leeuwenhoek 77:369-377

> Lom J (1987) Myxosporea: a new look at long known parasites of fish. Parasitol Today 3:327-332

Lom J, Dykova I (1992) Myxosporidia (phylum Myxozoa). In: Lom J, Dykova I (eds) Protozoan parasites of fishes. Elsevier, Amsterdam, p 159-236

> Miwa S, Nakayasu C, Kamaishi T, Yoshiura Y (2004) X-cells in fish pseudotumours are parasitic protozoans. Dis Aquat Org 58:165-170

> Nilsen F (2000) Small subunit ribosomal DNA phylogeny of Microsporidia with particular reference to genera that infect fish. J Parasitol 86:128-133

PIRSA (2003) PIRSA fact sheet: mulloway aquaculture in South Australia. www.pir.sa.gov.au/_data/assets/pdf_file /0006/33981/mulloway.pdf

Rand TG, White K, Cannone JJ, Gutell RR, Murphy CA, Ragan MA (2000) Ichthyophonus irregularis sp. nov. from the yellowtail founder Limanda ferruginea from the Nova Scotia shelf. Dis Aquat Org 41:31-36

Saunders GW, Kraft GT (1994) Small-subunit rRNA gene sequences from representatives of selected families of the Gigartinales and Rhodymeniales (Rhodophyta). 1. 
Evidence for the Plocamiales ord. nov. Can J Bot 72 : 1250-1263

Silberschneider V, Gray CA (2008) Synopsis of biological, fisheries and aquaculture-related information on mullowayArgyrosomus japonicus (Pisces: Scianidae), with particular reference to Australia. J Appl Ichthyology 24: $7-17$

Silberschneider V, Gray CA, Stewart J (2009) Age, growth, maturity and overfishing of the iconic scianid, Argyrosomus japonicus, in south-eastern Australia. Fish Res 95: 220-229

Whipps CM, Adlard RD, Bryant MS, Lester RJG, Findlay V, Kent ML (2003) First report of three Kudoa species from eastern Australia: Kudoa thyrsites from mahi mahi

Editorial responsibility: Mike Hine, Fouras, France
(Coryphaena hippurus), and Kudoa amamiensis and Kudoa minithyrsites n. sp. from sweeper (Pempherisy psilychnus). J Eukaryot Microbiol 50:215-219

White TJ, Bruns T, Lee S, Taylor J (1990) Amplification and direct sequencing of fungal ribosomal RNA gene for phylogenetics. In: Innis MA, Gelfand DH, Sninsky JJ, White TJ (eds) PCR protocols. Academic Press, San Diego, CA, p 315-322

Whittington ID (1996) Benedeniine capsalid monogeneans from Australian fishes: pathogenic species, site-specificity and camouflage. J Helminthol 70:177-184

Wolf K, Markiw ME (1979) Myxosoma cerebralis: a method for staining spores and other stages with silver nitrate. J Fish Res Board Can 36:88-89

Submitted: October 19, 2011; Accepted: June 18, 2012 Proofs received from author(s): August 7, 2012 